\title{
The Effect of Climate Change on Linolenic Fatty Acid in Oilseed Rape
}

\author{
Marek Wójtowicz ${ }^{1}$ and Andrzej Wójtowicz ${ }^{2, *}$ \\ 1 Plant Breeding and Acclimatization Institute, Research Division in Poznań, 60-479 Poznań, Poland; \\ marekw@nico.ihar.poznan.pl \\ 2 Institute of Plant Protection-National Research Institute, 60-318 Poznań, Poland \\ * Correspondence: a.wojtowicz@iorpib.poznan.pl; Tel.: +48-608-648-909
}

Received: 14 July 2020; Accepted: 16 December 2020; Published: 20 December 2020

\begin{abstract}
Linolenic acid content plays a significant role in the quality of oilseed rape oil. With the use of a model developed to calculate linolenic acid content depending on temperature, we performed simulations focused on the predicted changes of linolenic acid content triggered by expected climate change. The aim of the study was realized with the use of meteorological data recorded at 16 locations, representing 16 provinces in Poland, in the period of 1986-2005, and values obtained after the transformation of the recorded data to reflect temperature changes in four different representative concentration pathway scenarios (RCP2.6, RCP4.5, RCP6.0, RCP8.5) according to the gfdl_esm2m climate model. The results of the simulations performed under all tested scenarios (RCP2.6, RCP4.5, RCP6.0, RCP8.5) for all analyzed periods (2020-2039, 2040-2059, 2060-2079, 2080-2099) indicate a reduction of linolenic acid content as an effect of climate change. The comparison of simulation results obtained with and without allowing for the influence of temperature on oilseed rape development revealed the dominant role of direct influence in modifying the linolenic acid content. An analysis of the results also indicated how indirect influence of climate change, as expressed in changes of linolenic acid content generated by the acceleration of oilseed rape maturation, reduces the direct influence of climate change, expressed in changes of linolenic acid content caused by temperature. Additionally, simulation results point to opportunities, triggered by climate change, for a diversity of regions in terms of linolenic acid content in comparison to the years of 1986-2005.
\end{abstract}

Keywords: oilseed rape; linolenic acid content; climate change

\section{Introduction}

Oilseed rape is one of the most important oilseed crops in the world [1-3]. The major producers of this crop are China, India, Canada, and the European Union [4]. World production of oilseed rape is increasing very rapidly [5-8]. In Poland, due to increased demand for raw materials for biofuels, production of oilseed rape cultivation has increased by almost double over the last two decades, from 466 ha in 1998 to 823 thousand ha in 2017 [9]. Oilseed rape oil is used for various purposes, mainly human nutrition and as a raw material in the chemical industry. The residues from oil production are used as valuable animal forage [10]. The oil content of oilseed rape varies from $45 \%$ to $50 \%$ [11] depending on fertilization, variety, and meteorological conditions, and temperature plays a leading role in the modification of oilseed rape quantity and the balance between saturated, mono-unsaturated, and polyunsaturated fatty acids [12]. The effects of temperature on fatty acid content have been studied previously. Many reports indicate that cold and heat can affect fatty acid composition in oilseed rape and especially linolenic acid content [13-18]. Hence, it can be assumed that there is a high probability that climate change will also alter the content of fatty acids. Unfortunately, 
the limited literature dealing with this problem does not help to answer the question of quantitative changes of fatty acids content induced in oilseed rape by expected climate change.

To predict future changes in linolenic acid content in winter oilseed rape due to climate change, we used four representative concentration pathway scenarios (RCP2.6, RCP4.5, RRCP6.0, and RCP8.5) proposed by the IPCC $[19,20]$. RCP2.6 is the mitigation scenario. Its radiative forcing level will first reach a value of around $3.1 \mathrm{~W} / \mathrm{m}^{2}$ by the mid-century, and return to $2.6 \mathrm{~W} / \mathrm{m}^{2}$ by 2100 [21]. RCP4.5 [22-24] and RCP6.0 [25,26] are the stabilization scenarios in which total radiative forcing will be stabilized shortly after 2100 at the level of 4.5 and $6.0 \mathrm{~W} / \mathrm{m}^{2}$, respectively. RCP 8.5 is the "baseline" scenario that does not include any target of climate mitigation. According to this scenario, increased greenhouse gas emissions may lead to a radiative forcing of $8.5 \mathrm{~W} / \mathrm{m}^{2}$ by the end of the century [27].

The aim of the study was to investigate the predicted effect of climate change on linolenic fatty acid in oilseed rape in Poland, as well as to indicate the regions where changes in the content of the acid are expected to be the highest. An additional goal was to determine the relationship between the direct and indirect influences of climate change on the analyzed parameter.

Knowledge on the effects of climate changes on linolenic acid gained from this study may be helpful in determining the goals of oilseed rape breeding in the future.

\section{Materials and Methods}

\subsection{Development of Models Predicting the Beginning of Oilseed Rape Maturation}

The models were developed based on data obtained in field experiments conducted at Winna Góra (60 km south of Poznań) in 2007-2011. Each year, three cultivars were used in the study (Table 1). The model development consisted of quantifying the relationship between the accumulated degree days and the phenological development stages of the oilseed rape cultivars listed in Table 1, according to $\mathrm{BBCH}$ scale [28]. Observation were conducted twice a week in the period from the 1st of March to the beginning of oilseed rape maturation ( $\mathrm{BBCH} 81)$. For that period, accumulated degree days were calculated by adding daily temperature above $0{ }^{\circ} \mathrm{C}$. Six models were developed using monomolecular, Gompertz, logistic, and exponential functions. Three of the models were additionally mixed in four combinations (Table 2).

Table 1. Cultivars used in the experiments aimed at model development.

\begin{tabular}{cccc}
\hline Year & \multicolumn{3}{c}{ Cultivars } \\
\hline 2007 & Kaszub & Lisek & Bazyl \\
2008 & Californium & Lisek & Bazyl \\
2009 & Californium & Lisek & Bazyl \\
2010 & Californium & Elektra & Bazyl \\
2011 & Californium & Lisek & Bazyl \\
\hline
\end{tabular}

Table 2. Models used for predicting oilseed rape maturation.

\begin{tabular}{ccc}
\hline Abbreviation & Description & Formula \\
\hline $\mathrm{m}$ & Monomolecular & $\mathrm{BBCH}=\mathrm{a} 1 \times(1-\exp (-(\mathrm{a} 2+\mathrm{a} 3 \times \mathrm{DD})))$ \\
$\mathrm{G}$ & Gompertz & $\mathrm{BBCH}=\mathrm{b} 1 \times \mathrm{Exp}(-\mathrm{Exp}(-(\mathrm{b} 2+\mathrm{b} 3 \times \mathrm{DD})))$ \\
lo & logistic & $\mathrm{BBCH}=\mathrm{c} 1 /(1+\exp (-(\mathrm{c} 2+\mathrm{c} 3 \times \mathrm{DD})))$ \\
$\mathrm{M}+\exp$ & Monomolecular + exponential & $\mathrm{BBCH}=\mathrm{a} 1 \times(1-\exp (-(\mathrm{a} 2+\mathrm{a} 3 \times \mathrm{DD})))+$ \\
& & $\exp (-(\mathrm{a} 4 \times \mathrm{DD}))$ \\
\hline
\end{tabular}


Table 2. Cont.

\begin{tabular}{|c|c|c|}
\hline Abbreviation & Description & Formula \\
\hline G+exp & Gompertz + exponential & $\begin{array}{c}\mathrm{BBCH}=\mathrm{b} 1 \times \operatorname{Exp}(-\operatorname{Exp}(-(\mathrm{b} 2+\mathrm{b} 3 \times \\
\mathrm{DD})))+\exp (-(\mathrm{b} 4 \times \mathrm{DD}))\end{array}$ \\
\hline lo+exp & Logistic + exponential & $\begin{array}{c}\mathrm{BBCH}=\mathrm{c} 1 /(1+\exp (-(\mathrm{c} 2+\mathrm{c} 3 \times \\
\mathrm{DD})))+\exp (-(\mathrm{c} 4 \times \mathrm{DD}))\end{array}$ \\
\hline $\begin{array}{l}\text { Mean of }(\mathrm{m}+\mathrm{exp}) \& \\
(\mathrm{G}+\exp )\end{array}$ & $\begin{array}{c}\text { Mean of: } \\
\text { (Monomolecular + exponential) \& } \\
(\text { Gompertz + exponential })\end{array}$ & $\begin{array}{c}\mathrm{BBCH}=((\mathrm{a} 1 \times(1-\exp (-(\mathrm{a} 2+\mathrm{a} 3 \times \\
\mathrm{DD})))+\exp (-(\mathrm{a} 4 \times \mathrm{DD}))) \\
+(\mathrm{b} 1 \times \operatorname{Exp}(-\operatorname{Exp}(-(\mathrm{b} 2+\mathrm{b} 3 \times \mathrm{DD}))) \\
+\exp (-(\mathrm{b} 4 \times \mathrm{DD})))) / 2\end{array}$ \\
\hline $\begin{array}{l}\text { Mean of }(\mathrm{m}+\exp ) \& \\
(\mathrm{lo}+\exp )\end{array}$ & $\begin{array}{c}\text { Mean of: } \\
\text { (Monomolecular + exponential) \& } \\
(\text { logistic \& exponential) }\end{array}$ & $\begin{array}{c}\mathrm{BBCH}=((\mathrm{a} 1 \times(1-\exp (-(\mathrm{a} 2+\mathrm{a} 3 \times \\
\mathrm{DD})))+\exp (-(\mathrm{a} 4 \times \mathrm{DD}))) \\
+(\mathrm{b} 1 / \mathrm{b} 1+\exp (-(\mathrm{b} 2+\mathrm{b} 3 \times \mathrm{DD})))+ \\
\exp (-(\mathrm{b} 4 \times \mathrm{DD})))) / 2\end{array}$ \\
\hline $\begin{array}{c}\text { Mean of }(\mathrm{G}+\exp ) \& \\
(\mathrm{lo}+\exp )\end{array}$ & $\begin{array}{c}\text { Mean of: } \\
\text { (Gompertz + exponential) } \\
\& \text { (logistic + exponential) }\end{array}$ & $\begin{array}{c}\mathrm{BBCH}=((\mathrm{b} 1 \times \operatorname{Exp}(-\operatorname{Exp}(-(\mathrm{b} 2+\mathrm{b} 3 \\
\times \mathrm{DD})))+\exp (-(\mathrm{b} 4 \times \mathrm{DD})))) \\
+((\mathrm{c} 1 /(1+\exp (-(\mathrm{c} 2+\mathrm{c} 3 \times \mathrm{DD})))+ \\
\exp (-(\mathrm{c} \times \mathrm{DD})))) / 2\end{array}$ \\
\hline $\begin{array}{c}\text { Mean of }(m+\exp ) \\
\&(G+\exp ) \&(l o+e x p)\end{array}$ & $\begin{array}{c}\text { Mean of: } \\
\text { (Monomolecular + exponential) \& } \\
\text { Gompertz + exponential) } \\
\& \text { (logistic + exponential) }\end{array}$ & $\begin{array}{c}\mathrm{BBCH}=((\mathrm{a} 1 \times(1-\exp (-(\mathrm{a} 2+\mathrm{a} 3 \times \\
\mathrm{DD})))+\exp (-(\mathrm{a} 4 \times \mathrm{DD}))) \\
+(\mathrm{b} 1 \times \operatorname{Exp}(-\operatorname{Exp}(-(\mathrm{b} 2+\mathrm{b} 3 \times \mathrm{DD}))) \\
+\exp (-(\mathrm{b} 4 \times \mathrm{DD}))) \\
+(\mathrm{c} 1 /(1+\exp (-(\mathrm{c} 2+\mathrm{c} 3 \times \mathrm{DD})))+ \\
\exp (-(\mathrm{c} 4 \times \mathrm{DD})))) / 3\end{array}$ \\
\hline
\end{tabular}

\subsection{Selection of A Model for Simulating Oilseed Rape Maturation}

The selection of the model for simulating oilseed rape maturation was made using a Taylor diagram [29]. This diagram provides a visual framework to compare the results of the models to the observations. The simulated and observed dates of the beginning of maturation (BBCH 81) of oilseed rape cultivars listed in Table 3 were compared. The simulations were performed using meteorological data registered from March to July at Winna Góra from 2012-2016. Observation results came from field experiments conducted at the same location and time with the use of cultivars listed in the Table 3.

Table 3. Cultivars used in the experiments aimed at model selection.

\begin{tabular}{cccc}
\hline Year & & Cultivars & \\
\hline 2011 & Californium & Nelson & Visbi \\
2012 & Artoga & Strater & Visbi \\
2013 & Artoga & Starter & Visbi \\
2014 & Bogart & Artoga & Poznaniak \\
2015 & Bogart & Kaszub & Poznaniak \\
\hline
\end{tabular}

\subsection{Simulation of the Effect of Climate Change on Linolenic Acid Content}

The simulations were performed using both real and virtual meteorological data. The real data was from the period from 1986 to 2005 at 16 locations in Poland (Figure 1), while the virtual data was obtained after the transformation of the recorded data to reflect temperature changes under RCP2.6 RCP4.5 RCP6.0, and RCP8.5 scenarios according to the 16 climate model presented on the Climate Change Knowledge Portal created by the World Bank (http://sdwebx.worldbank.org/climateportal/) (Table 4). Data transformation was based on the delta change approach, which consists of adding the time mean temperature change between the baseline and scenario simulations to each daily value in the observed time series according to the Equation (1):

$$
\text { Tdb }=\text { Tobsref }+(\text { Tsimeval }- \text { Tsimref })
$$


where:

$\mathrm{Tdb}$-debiased temperature;

Tobsref-daily temperature observed in the reference period;

Tsimproj-monthly temperature simulated for the projected period;

Tsimref-monthly temperature simulated for the reference period.

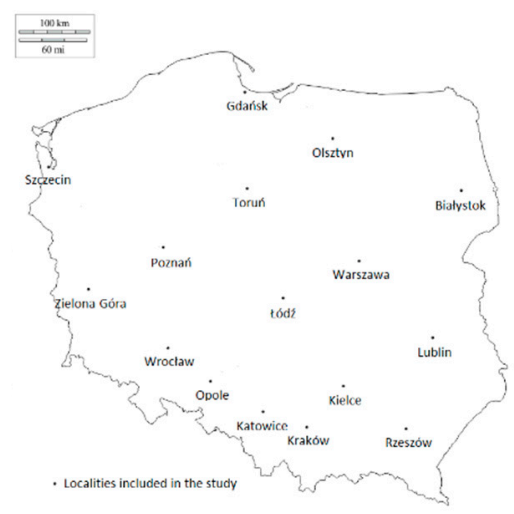

Figure 1. Distribution of the localities included in the study.

Table 4. List of climate models used in the study.

\begin{tabular}{ll}
\hline Model & \\
\hline bcc_csm1_1 & Beijing Climate Center, China \\
bcc_csm1_1_m & Beijing Climate Center, China \\
ccsm4 & National Center for Atmospheric Research (NCAR), USA \\
cesm1_cam5 & Community Earth System Model Contributors, USA \\
csiro_mk3_6_0 & Commonwealth Scientific and Industrial Research Organization/Queensland \\
fio_esm & Climate Change Centre of Excellence, Australia \\
gfdl_cm3 & The First Institute of Oceanography, SOA, China \\
gfdl_esm2m & Geophysical Fluid Dynamics Laboratory, USA \\
giss_e2_h & Geophysical Fluid Dynamics Laboratory, USA \\
giss_e2_r & Goddard Institute for Space Studies (NASA), USA \\
ipsl_cm5a_mr & Goddard Institute for Space Studies (NASA), USA \\
& Institut Pierre-Simon Laplace, France \\
miroc_esm & Japan Agency for Marine-Earth Science and Technology, Atmosphere and Ocean \\
& Research Institute (The University of Tokyo), and National Institute for \\
& Environmental Studies, Japan \\
miroc_esm_chem & Japan Agency for Marine-Earth Science and Technology, Atmosphere and Ocean \\
& Research Institute (The University of Tokyo), and National Institute for \\
& Environmental Studies, Japan \\
miroc5 & Atmosphere and Ocean Research Institute (The University of Tokyo), National \\
& Institute for Environmental Studies, and Japan Agency for Marine-Earth Science \\
mri_cgcm3 & and Technology, Japan \\
noresm1_m & Meteorological Research Institute, Japan \\
\hline & Norwegian Climate Center, Norway \\
\hline
\end{tabular}

Two kinds of simulations were carried out in the study. The first generated results allowed for both the direct and indirect influence of temperature on linolenic acid content. The second set of results only allowed for the direct influence of temperature. The direct influence is based on the relation between temperature and linolenic acid content, while indirect influence recognizes the influence of temperature on the rate of oilseed rape development.

The difference between the two simulations was the way in which the date of the beginning of oilseed rape maturation was determined. 
In the first case, the sub-model simulating oilseed rape development was used both for the period of 1986-2005 as well as for the periods of 2020-2039, 2040-2059, 2060-2079, 2080-2099. In the second simulation, the dates of oilseed rape maturation indicated for the period of 1986-2005 were also used in simulations for the other periods.

For each location included in the study, 340 (20 years $\times 17$ sets of meteorological data) simulations were performed to assess linolenic acid content.

The task was completed in three steps. The first step was to determine the dates of the beginning of the oilseed rape maturation ( $\mathrm{BBCH} 81$ ). In the second step, the average temperature during the twenty days following the beginning of the oilseed rape maturation was calculated. The third step consisted of calculating the content of linoleic acid for each location (Białystok, Gdańsk, Katowice, Kielce, Kraków, Lublin, Łódź, Olsztyn, Opole, Poznań, Rzeszów, Szczecin, Torun, Warszawa, Wrocław, Zielona Góra), scenario (RCP2.6, RCP4.5, RCP6.0, RCP8.5), and period (2020-2039, 2040-2059, 2060-2079, 2080-2099) using Equation (2).

$$
\mathrm{Lac}=\mathrm{a} * \mathrm{~T}_{20}+\mathrm{b}
$$

where Lac is linoleic acid content; $\mathrm{T}_{20}$ is the average temperature $\left({ }^{\circ} \mathrm{C}\right)$ of the twenty days from the beginning of oilseed maturation; and $a, b$ the equation coefficients (Table 5 ).

Table 5. Parameters of the equation [ $\left.\mathrm{Lac}=\mathrm{a} * \mathrm{~T}_{20}+\mathrm{b}\right]$ expressing the influence of temperature on linolenic acid content in the seeds of winter oilseed rape.

\begin{tabular}{cccccc}
\hline \multirow{2}{*}{ Values of Coefficient } & \multicolumn{4}{c}{ Statistical Values } \\
\cline { 3 - 4 } & $\mathbf{3}$ & \multicolumn{3}{c}{$\boldsymbol{p}$-Values } \\
\cline { 3 - 5 } $\mathbf{a}$ & $\mathbf{b}$ & $\mathbf{b}$ & \\
\hline-0.4241 & 17.2887 & 0.000 & 0.000 & 0.49 \\
\hline
\end{tabular}

Equation (2) was developed on the basis of the data acquired by Wójtowicz [30] in the experiments conducted with the use of two cultivars: Bojan (open-pollinated) and Kronos (restored hybrid) in two localities in Poland: Małyszyn (52.44 N, 15.10 E) and Zielęcin (52.10 N, 16.22 E) in the period of 2006-2008. The accuracy of the model was tested in the experiments carried out in Łagiewniki (51.46 N, 17.14 E) in 2006-2008. Each cultivar was tested each year on 36 plots. There were 432 results obtained for model development, and 216 for its validation this way. Values of statistical parameters of the equation describing the agreement between the registered and modeled linolenic acid content in Łagiewniki are summarized in Table 6 . High $R^{2}$ values, equal to 0.87 , ensure the predictive model fits the data well.

Table 6. Parameters of the equation representing exact agreement between registered and simulated linolenic acid content in the seeds of winter oilseed rape grown in Łagiewniki in 2006-2008.

\begin{tabular}{cccccc}
\hline \multirow{2}{*}{ Values of Coefficient } & \multicolumn{4}{c}{ Statistical Values } \\
\cline { 3 - 5 } & $\mathbf{3}$ & \multicolumn{3}{c}{$\boldsymbol{p}$-Values } \\
\cline { 3 - 5 } $\mathbf{a}$ & $\mathbf{b}$ & $\mathbf{a}$ & $\mathbf{b}$ & \\
\hline 0.6305 & 3.6819 & 0.000 & 0.000 & 0.87 \\
\hline
\end{tabular}

The direct influence of temperature on linoleic acid content was calculated using Equation (3).

$$
\text { ID = Lac-tor i, j - Lac1986-2005 }
$$

where ID is the direct impact of climate change on linoleic acid content; Lac-tor $i, j$ is the linoleic acid content obtained from simulations without allowing for the influence of temperature on development of oilseed rape for the i scenario and j period (i: RCP2.6, RCP4.5, RCP6.0, RCP8.5; j: 2020-2039, 
2040-2059, 2060-2079, 2080-2099); and Lac1986-2005 is the linoleic acid content obtained in simulations for the period of 1986-2005.

The sum of the direct and indirect impact of climate change on linoleic acid content was calculated using Equation (4).

$$
\mathrm{I}(\mathrm{D}+\mathrm{I})=\text { Lac+tor } \mathrm{i}, \mathrm{j}-\text { Lac1986-2005 }
$$

where $\mathrm{I}(\mathrm{D}+\mathrm{I})$ is the sum of the direct and indirect impact of climate change on linoleic acid content; Lac+tor $i, j$ is the linoleic acid content obtained in simulations allowing for the influence of temperature on the development of oilseed rape for the i scenario and j period (i: RCP2.6, RCP4.5, RCP6.0, RCP8.5; j: 2020-2039, 2040-2059, 2060-2079, 2080-2099); and Lac1986-2005 is the linoleic acid content obtained in simulations for the period of 1986-2005.

The indirect impact of climate change on linoleic acid content was calculated using Equation (5).

$$
\mathrm{II}=\mathrm{I}(\mathrm{D}+\mathrm{I})-\mathrm{ID}
$$

where II is the indirect impact of climate change on linoleic acid content; I(D + I) is the sum of the direct and indirect impact of climate change on linoleic acid content; and ID is the direct impact of climate change on linoleic acid content.

Additionally, with the use of the Euclidean distance between each pair of the linolenic acid content obtained in simulations allowing for both direct and indirect influence of climate change on linolenic acid content, we performed a territorial division for regions that share similar values based on complete (or maximum) clustering methodology. This method computes all pairwise dissimilarities between the elements in cluster 1 and the elements in cluster 2, and considers the largest value (i.e., maximum value) of these dissimilarities as the distance between the two clusters. The complete clustering algorithm gave compact clusters that were then split with the threshold value of Euclidean distance equaling 0.2, as shown in Figure 2.

\section{Cluster Dendrogram}

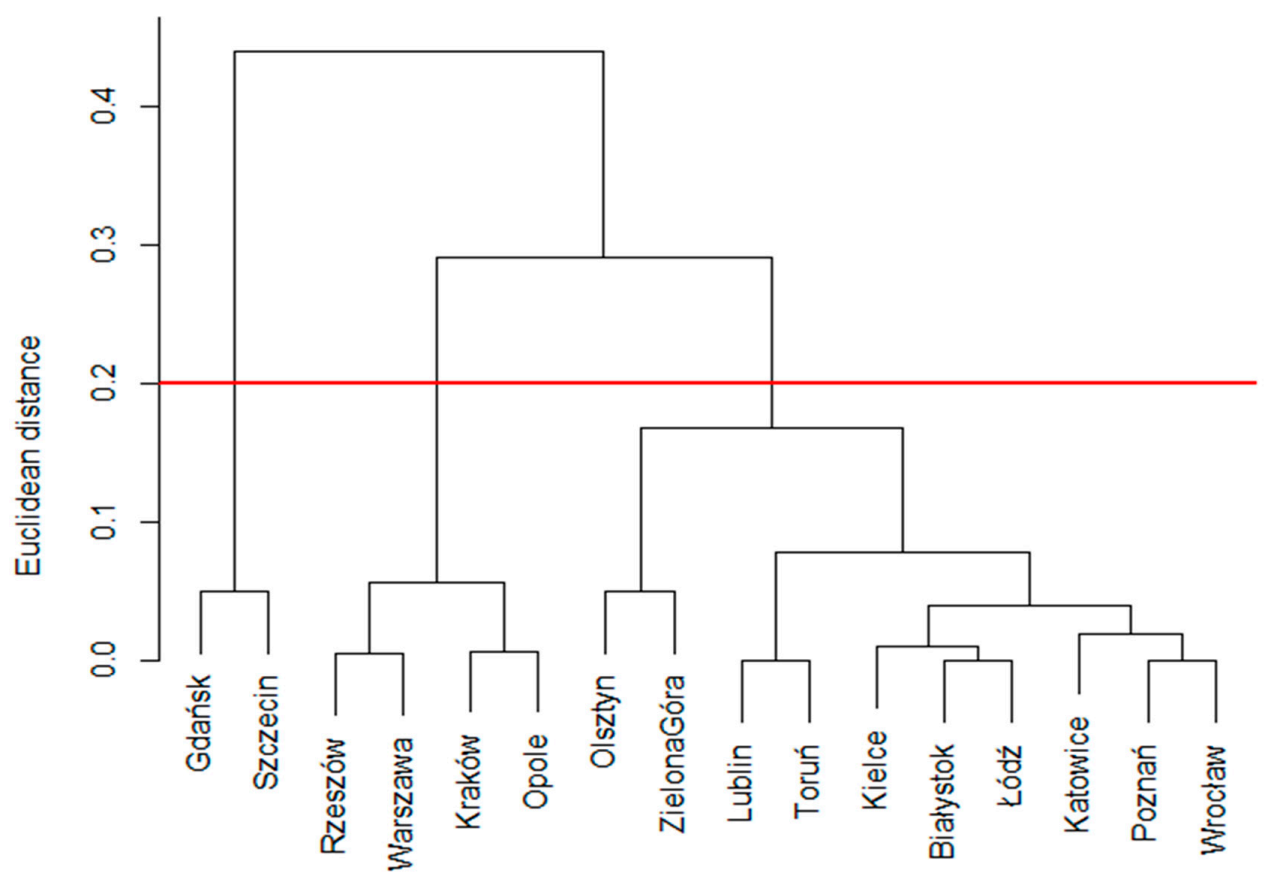

Figure 2. Grouping dendrogram based on the linolenic acid content predicted for the period of 2020-2039. The red horizontal line denotes the threshold value of the Euclidean distance at the end step of the grouping method. 


\section{Results}

\subsection{The Development of Models Predicting the Beginning of Oilseed Rape Maturation}

The maturation of oilseed rape was dependent on the year of the study, but not on the cultivar used.

In the experiments conducted in the period of 2007-2011, the earliest symptoms of oilseed rape maturation was noticed in 2008 (9.06), while the latest was in 2010 (25.06) (Table 7).

Table 7. Dates of the beginning of maturation of oilseed rape cultivars in the years of 2007-2011.

\begin{tabular}{ccccccc}
\hline Year & Cultivar & $\begin{array}{c}\text { Beginning of } \\
\text { Oilseed Rape } \\
\text { Maturation }\end{array}$ & Cultivar & $\begin{array}{c}\text { Beginning of } \\
\text { Oilseed Rape } \\
\text { Maturation }\end{array}$ & Cultivar & $\begin{array}{c}\text { Beginning of } \\
\text { Oilseed Rape } \\
\text { Maturation }\end{array}$ \\
\hline 2007 & Kaszub & 11.06 & Lisek & 11.06 & Bazyl & 11.06 \\
2008 & Californium & 9.06 & Lisek & 9.06 & Bazyl & 9.06 \\
2009 & Californium & 15.06 & Lisek & 15.06 & Bazyl & 15.06 \\
2010 & Californium & 25.06 & Elektra & 25.06 & Bazyl & 25.06 \\
2011 & Californium & 15.06 & Lisek & 15.06 & Bazyl & 15.06 \\
\hline
\end{tabular}

Six temperature-response models and four combinations of the models composed of two functions (monomolecular and exponential, Gompertz and exponential, logistic + exponential) were used to express the relationship between oilseed rape maturation and accumulated degree days. The values of the coefficients of the models and statistical values for the models used are summarized in Table 8.

Table 8. Parameters of the models used for predicting oilseed rape maturation.

\begin{tabular}{|c|c|c|c|c|c|c|c|c|c|}
\hline \multirow{3}{*}{ Model } & \multirow{2}{*}{\multicolumn{4}{|c|}{ Value of Coefficients in the Model }} & \multicolumn{5}{|c|}{ Statistical Values } \\
\hline & & & & & \multicolumn{4}{|c|}{$p$-Values } & \multirow{2}{*}{$\mathbf{R}^{2}$} \\
\hline & $\mathrm{a} 1 / \mathrm{b} 1 / \mathrm{c} 1$ & $\mathrm{a} 1 / \mathrm{b} 1 / \mathrm{c} 1$ & $\mathbf{a} 1 / \mathbf{b} 1 / \mathbf{c} 1$ & $\mathbf{a} 1 / \mathbf{b} 1 / \mathrm{c} 1$ & a1/b1/c1 & $\mathrm{a} 1 / \mathrm{b} 1 / \mathrm{c} 1$ & $\mathrm{a} 1 / \mathrm{b} 1 / \mathrm{c} 1$ & $\mathbf{a} 1 / \mathbf{b} 1 / \mathbf{c} 1$ & \\
\hline $\mathrm{m}$ & 94.8288 & 0.2203 & 0.0017 & & 0.00000 & 0.00000 & 0.00000 & & 95 \\
\hline G & 90.5217 & -0.3376 & 0.0027 & & 0.00000 & 0.00000 & 0.00000 & & 94 \\
\hline lo & 88.5426 & -0.9479 & 0.0037 & & 0.00000 & 0.00000 & 0.00000 & & 93 \\
\hline $\mathrm{m}+\exp$ & 77.1172 & 0.2118 & 0.0028 & -0.0017 & 0.00000 & 0.000000 & 0.00000 & 0.0000 & 96 \\
\hline$G+\exp$ & 73.6401 & -0.3743 & 0.0044 & -0.0018 & 0.00000 & 0.000000 & 0.00000 & 0.0000 & 96 \\
\hline lo+exp & 73.6401 & -0.3743 & 0.0044 & -0.0018 & 0.00000 & 0.000000 & 0.00000 & 0.0000 & 95 \\
\hline
\end{tabular}

\subsection{Selection of a Model for Simulating Oilseed Rape Maturation}

Similar to the experiments aimed at the model development, no differences in the beginning of maturation between cultivars used in the years of 2012-2016 were observed. Again, maturity of oilseed rape was triggered by meteorological conditions and started between the 2nd and 26th of June (Table 9).

Table 9. Dates of the beginning of maturation of oilseed rape cultivars in the years of 2012-2016.

\begin{tabular}{ccccccc}
\hline Year & Cultivar & $\begin{array}{c}\text { Beginning of } \\
\text { Oilseed Rape } \\
\text { Maturation }\end{array}$ & Cultivar & $\begin{array}{c}\text { Beginning of } \\
\text { Oilseed Rape } \\
\text { Maturation }\end{array}$ & Cultivar & $\begin{array}{c}\text { Beginning of } \\
\text { Oilseed Rape } \\
\text { Maturation }\end{array}$ \\
\hline 2012 & Californium & 15.06 & Nelson & 15.06 & Visbi & 15.06 \\
2013 & Artoga & 26.06 & Strater & 26.06 & Visbi & 26.06 \\
2014 & Artoga & 2.06 & Starter & 2.06 & Visbi & 2.06 \\
2015 & Bogart & 26.06 & Artoga & 26.06 & Poznaniak & 26.06 \\
2016 & Bogart & 13.06 & Kaszub & 13.06 & Poznaniak & 13.06 \\
\hline
\end{tabular}


The differences between the observation and simulation results depending on the year, and the model ranged between 0 and 22 days (Table 10). The results of the m+exp model and the mean values of results of the $\mathrm{m}+\exp$ and $\mathrm{G}+\exp$ models, as well as the $\mathrm{m}+\mathrm{exp}$ and lo+exp models, did not differ with observation by more than 9 days. The comparison of the G+exp model and the mean values of the three models ( $m+\exp$ and $\mathrm{G}+\exp$ and lo+exp) with the results of the observations revealed that the differences did not exceeded 10 days, whereas the maximum disagreement between the mean values of the results of the G+exp and lo+exp models and observations was 11 days. A one-day maximum disagreement between the model results and real data appeared as an effect of the use of the lo+exp model. The other models generated results which differed with observations by $18(\mathrm{~m}), 20(\mathrm{G})$, and 22 (lo) days.

The use of a Taylor diagram revealed that combining the results of the two models ( $m+e x p$ and lo+exp) appeared on the plot at the smallest distance from the observation point (Figure 3). Based on the results obtained using the diagram, this combination of models was selected for further analysis.

\section{Taylor Diagram}

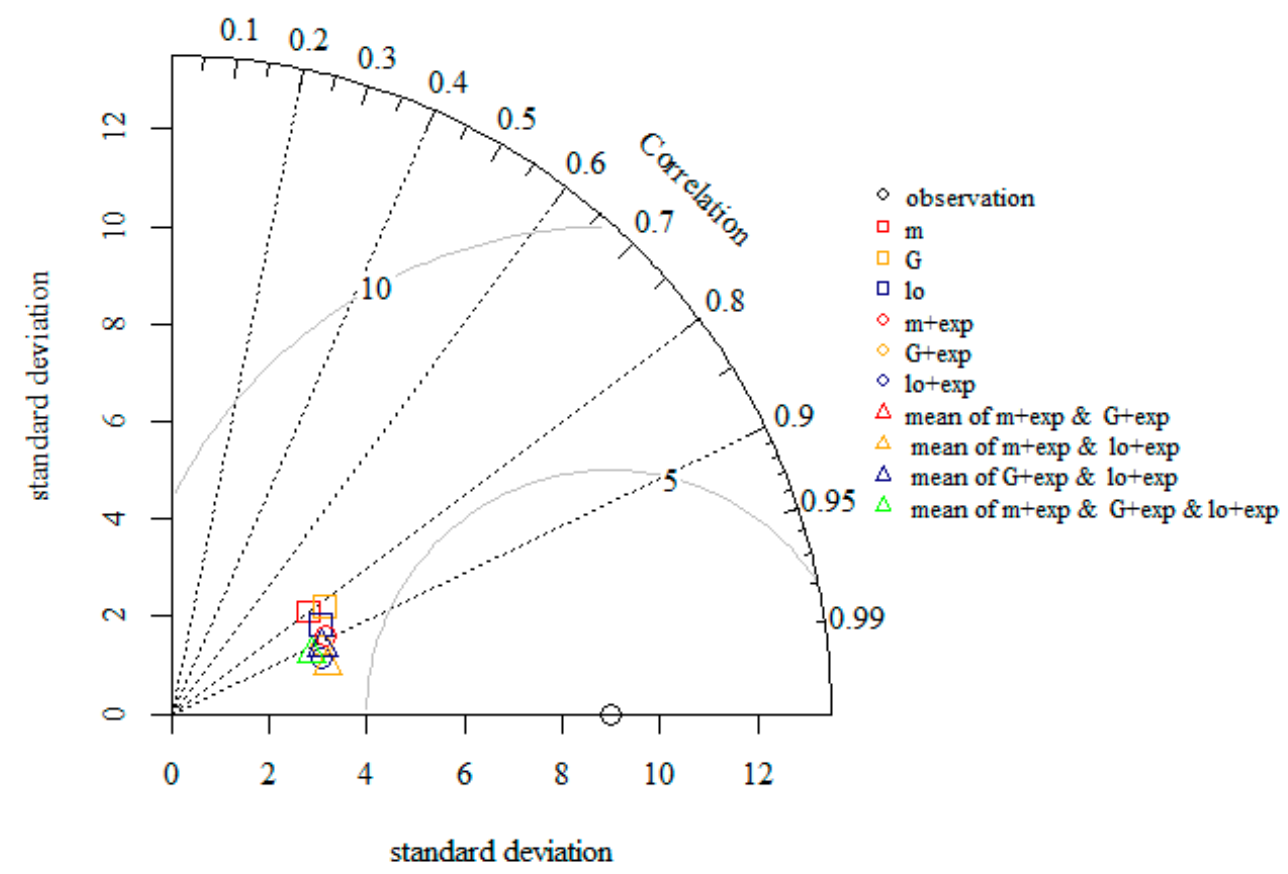

Figure 3. A Taylor diagram illustrating the statistics of the comparison between the observed and model estimates of the beginning of oilseed rape maturation in 2012-2016. 
Table 10. Comparison of the observed beginning of oilseed rape maturation and simulated with the use of models listed in Table 2.

\begin{tabular}{|c|c|c|c|c|c|c|c|c|c|c|c|}
\hline \multirow[b]{2}{*}{ Year } & \multirow[b]{2}{*}{$\begin{array}{c}\text { Results of } \\
\text { Observations }\end{array}$} & \multicolumn{10}{|c|}{ Results of the Simulations } \\
\hline & & $\mathbf{m}$ & G & lo & $\mathrm{m}+\exp$ & $G+\exp$ & $10+\exp$ & $\begin{array}{c}\text { Mean of } \\
\text { m+exp } \\
\& \\
\text { G+exp }\end{array}$ & $\begin{array}{c}\text { Mean of } \\
\text { m+exp } \\
\& \\
\text { lo+exp }\end{array}$ & $\begin{array}{c}\text { Mean of } \\
\text { G+exp } \\
\& \\
\text { lo+exp }\end{array}$ & $\begin{array}{c}\text { Mean of } \mathrm{m}+\exp \\
\& \\
\text { G+ex } \\
\& \\
\text { lo+exp }\end{array}$ \\
\hline 2012 & 15.06 & 2.06 & 29.05 & 28.05 & 11.06 & 13.06 & 16.06 & 12.06 & 13.06 & 14.06 & 13.06 \\
\hline 2013 & 26.06 & 11.06 & 9.06 & 7.06 & 18.06 & 19.06 & 21.06 & 18.06 & 19.06 & 20.06 & 19.06 \\
\hline 2014 & 2.06 & 3.06 & 31.05 & 28.05 & 10.06 & 12.06 & 14.06 & 11.06 & 11.06 & 13.06 & 12.06 \\
\hline 2015 & 26.06 & 8.06 & 6.06 & 4.06 & 17.06 & 20.06 & 22.06 & 18.06 & 19.06 & 21.06 & 19.06 \\
\hline 2016 & 13.06 & 3.06 & 1.06 & 30.05 & 10.06 & 13.06 & 15.06 & 12.06 & 13.06 & 14.06 & 13.06 \\
\hline
\end{tabular}




\subsection{Simulation of the Effect of Climate Change on the Beginning of Oilseed Rape Maturation}

A simulation based on data registered in 16 analyzed locations performed with the model obtained by combining the two model results $(\mathrm{m}+\exp$ and $\mathrm{lo}+\exp$ ) revealed that oilseed rape maturation started between 162 and 179 days after the 1st of January (Table 11). For the period of 2020-2039, depending on the RCP scenario, the simulation showed a reduction of the time needed for the oilseed rape to start maturation by 12-17 (RCP2.6), 13-19 (RCP4.5), 11-16 (RCP6.0), and 14-19 days (RCP8.5). For 2040-2059, the reductions were respectively 14-19 (RCP2.6), 16-22 (RCP4.5), 16-21 (RCP6.0), and 20-25 days (RCP8.5). For 2060-2079, the minimum and maximum reductions ranged between 15 and 19 (RCP2.6), 19 and 24 (RCP4.5), 19 and 24 (RCP6.0), and 27 and 32 (RCP8.5). For 2080-2099, the simulation generated a reduction of the period from the 1st of June to the beginning of maturation of 14-18 days (RCP2.6), 20-25 days (RCP4.5), 22-28 days (RCP6.0), and 34-39 days (RCP8.5).

Table 11. The reduction of time needed for the oilseed rape to start maturation predicted for four scenarios (RCP2.6, RCP4.5, RCP6.0, RCP8.5) and four periods (2020-2039, 2040-2059, 2060-2079, 2080-2099) in comparison to those registered in the period of 1986-2005.

\begin{tabular}{|c|c|c|c|c|c|c|c|c|c|c|c|c|c|c|c|c|c|}
\hline \multirow{5}{*}{ Location } & \multirow{5}{*}{$\begin{array}{c}\text { Start of Oilseed } \\
\text { Rape Maturation } \\
\text { in the Period of } \\
1986-2005 \\
\text { [Day of the Year] }\end{array}$} & \multicolumn{16}{|c|}{$\begin{array}{c}\text { Reduction of Time Needed for the Oilseed Rape to Start } \\
\text { Maturation [Days] }\end{array}$} \\
\hline & & \multicolumn{16}{|c|}{ Period } \\
\hline & & \multicolumn{4}{|c|}{ 2020-2039 } & \multicolumn{4}{|c|}{ 2040-2059 } & \multicolumn{4}{|c|}{ 2060-2079 } & \multicolumn{4}{|c|}{ 2080-2099 } \\
\hline & & \multicolumn{16}{|c|}{ RCP Scenario } \\
\hline & & 26 & 45 & 60 & 85 & 26 & 45 & 60 & 85 & 26 & 45 & 60 & 85 & 26 & 45 & 60 & 85 \\
\hline Białystok & 173 & 13 & 14 & 11 & 14 & 15 & 17 & 16 & 21 & 15 & 20 & 20 & 29 & 14 & 21 & 23 & 35 \\
\hline Gdańsk & 179 & 15 & 17 & 14 & 17 & 17 & 20 & 19 & 24 & 18 & 23 & 23 & 32 & 16 & 24 & 27 & 39 \\
\hline Katowice & 166 & 14 & 15 & 13 & 15 & 16 & 18 & 18 & 22 & 16 & 21 & 21 & 29 & 15 & 22 & 24 & 35 \\
\hline Kielce & 170 & 13 & 14 & 11 & 14 & 14 & 17 & 16 & 21 & 15 & 20 & 20 & 28 & 14 & 20 & 23 & 34 \\
\hline Kraków & 165 & 14 & 15 & 12 & 15 & 16 & 18 & 17 & 22 & 16 & 20 & 21 & 28 & 15 & 21 & 24 & 35 \\
\hline Lublin & 170 & 12 & 13 & 11 & 14 & 14 & 16 & 16 & 20 & 15 & 19 & 19 & 27 & 14 & 20 & 22 & 34 \\
\hline Łódź & 167 & 14 & 15 & 12 & 15 & 15 & 18 & 17 & 21 & 16 & 20 & 20 & 28 & 15 & 21 & 24 & 34 \\
\hline Olsztyn & 173 & 14 & 15 & 12 & 15 & 15 & 18 & 17 & 22 & 16 & 21 & 21 & 30 & 14 & 22 & 24 & 36 \\
\hline Opole & 162 & 15 & 16 & 14 & 17 & 17 & 19 & 19 & 23 & 17 & 22 & 22 & 29 & 16 & 22 & 25 & 36 \\
\hline Poznań & 165 & 15 & 17 & 14 & 17 & 17 & 19 & 19 & 23 & 17 & 22 & 22 & 30 & 16 & 23 & 25 & 36 \\
\hline Rzeszów & 166 & 13 & 14 & 12 & 14 & 15 & 17 & 16 & 21 & 15 & 20 & 20 & 28 & 14 & 20 & 23 & 34 \\
\hline Szczecin & 167 & 17 & 19 & 16 & 19 & 19 & 22 & 21 & 25 & 19 & 24 & 24 & 32 & 18 & 25 & 28 & 39 \\
\hline Toruń & 167 & 15 & 16 & 13 & 16 & 16 & 19 & 18 & 22 & 17 & 21 & 21 & 30 & 15 & 22 & 25 & 36 \\
\hline Warszawa & 166 & 14 & 15 & 12 & 15 & 15 & 18 & 17 & 21 & 16 & 20 & 20 & 28 & 15 & 21 & 24 & 35 \\
\hline Wrocław & 164 & 16 & 17 & 15 & 17 & 18 & 20 & 19 & 24 & 18 & 23 & 23 & 31 & 17 & 24 & 26 & 37 \\
\hline $\begin{array}{l}\text { Zielona } \\
\text { Góra }\end{array}$ & 165 & 15 & 17 & 14 & 17 & 17 & 19 & 19 & 23 & 17 & 22 & 22 & 30 & 16 & 22 & 25 & 36 \\
\hline MIN & 162 & 12 & 13 & 11 & 14 & 14 & 16 & 16 & 20 & 15 & 19 & 19 & 27 & 14 & 20 & 22 & 34 \\
\hline MAX & 179 & 17 & 19 & 16 & 19 & 19 & 22 & 21 & 25 & 19 & 24 & 24 & 32 & 18 & 25 & 28 & 39 \\
\hline MEAN & 168 & 14 & 16 & 13 & 16 & 16 & 19 & 18 & 22 & 16 & 21 & 21 & 29 & 15 & 22 & 25 & 36 \\
\hline
\end{tabular}

\subsection{Simulation of Climate Change on Linolenic Acid Content}

The simulations performed allowing for the influence of climate change on the rate of oilseed rape development on real data revealed that the content of linoleic acid varied between 9.67 at Opole and 10.28 at Gdańsk (Table 12). For the period of 2020-2039, depending on the RCP scenario, the minimum 
and maximum content of acid were 9.87 at Rzeszów and 10.31 at Gdańsk for RCP2.6, 9.90 at Rzeszów and 10.39 at Gdańsk for RCP4.5, 9.89 at Warszawa and 10.32 at Gdańsk for RCP6.0, and 9.81 at Warszawa and 10.28 at Gdańsk for RCP8.5. For the period of 2040-2059, under the RCP2.6, RCP4.5, RCP6.0, and RCP8.5 scenarios, the minimum content of linolenic acid was obtained in simulations for Warszawa (respectively: 9.83, 9.71, 9.80, 9.65) whereas the maximum was for Gdańsk (respectively: $10.29,10.22,10.29,10.22)$. For the period of 2060-2079, for the scenario of RCP2.6, the minimum linolenic acid content was obtained for Opole (9.80), whereas the maximum was obtained for Gdańsk (10.31), while under RCP scenarios 4.5, 6.0, 8.5 were for Warszawa $(9.60,9.66,9.47)$ and for Gdańsk $(10.20,10.21,10.13)$. For 2080-2099, irrespective of the RCP scenario, the minimum and maximum linolenic acid content were revealed in simulations for Warszawa (respectively: 9.77, 9.62, 9.57, 9.47) and Gdańsk (respectively: 10.31, 10.23, 10.14, 10.08).

The coefficient of variation (CV) of linolenic acid content simulated for the period of 2020-2039 under four RCP scenarios varied between $0.24 \%$ and $0.69 \%$ (Table 12). For $75 \%$ of locations (twelve out of sixteen), the analyzed parameter was smaller than 0.46 . The minimum and maximum values of the coefficient of variation for the period of 2040-2059 were $0.40 \%$ and $0.92 \%$. The analyzed parameter was smaller than 0.80 for $75 \%$ of locations. For the period of 2060-2079, the coefficient of variation (CV) varied between $0.75 \%$ and $1.60 \%$. For twelve out of sixteen locations $(75 \%)$, the analyzed parameter was smaller than 1.42. Simulations for the period of 2080-2099 revealed that the value of the parameter ranged between $1.00 \%$ and $2.01 \%$, and for $75 \%$ of locations was smaller than 1.58 .

Simulations which didn't allow for the influence of climate change on the rate of oilseed rape development performed for the period of 2020-2039 revealed that the minimum and maximum content of the linolenic acid was 9.27 and 9.75 for RCP2.6, 9.29 and 9.76 for RCP4.5, 9.30 and 9.81 for RCP6.0, and 9.18 and 9.60 for RCP8.5 (Table 13). For the period of 2040-2059, under the RCP2.6, RCP4.5, RCP6.0, RCP8.5 scenarios, the minimum content of linolenic acid was, respectively: 9.15, 8.98, 9.05, 8.77; whereas the maximum was: $9.64,9.48,9.51,9.20$. For the period of 2060-2079, the minimum and maximum linolenic acid content was, respectively, 9.15 and 9.61 (RCP2.6), 8.78 and 9.30 (RCP4.5), 8.69 and 9.29 (RCP6.0), and 8.26 and 8.82 (RCP8.5). Simulations for the period of 2080-2099 revealed that the minimum acid content was 9.21 for RCP2.6, 8.78 for RCP4.5, 8.51 for RCP6.0, and 7.76 for RCP8.5; whereas the maximum was 9.68 for RCP2.6, 9.27 for RCP4.5, 8.99 for RCP6.0, and 8.27 for RCP8.5. Out of 16 combinations of period and scenario, the minimum acid content was registered as 15 times for Opole and 1 for Wrocław; whereas the maximum acid content was 16 times for Gdańsk.

Comparisons of linolenic acid content obtained in simulations performed with and without allowing for the influence of climate change on the rate of oilseed rape development revealed that under the RCP2.6 scenario, the former generated higher changes in the analyzed parameters irrespective of the analyzed period. (Table 14). Such situations also appeared in the periods of 2020-2039 and 2040-2059 under the RCP scenarios of 4.5 and 6.0, as well as in the period of 2020-2039 under the RCP8.5 scenario, while in the periods of 2060-2079 and 2080-2099 under the RCP scenarios of 4.5 and 6.0, as well as in the periods of 2040-2059, 2060-2079, and 2080-2099 under RCP8.5 scenario, direct influence was higher than indirect.

The differences between linolenic acid content obtained in simulations performed on registered data and on data reflecting climate change without the influence of temperature on oilseed rape development, which expresses the direct influence of climate change on the linolenic acid content, ranged between -0.55 and -0.39 for RCP2.6, -0.96 and -0.55 for RCP4.5, -1.43 and -0.56 for RCP6.0, -1.95 , and -0.51 for RCP85. On the other hand, the sum of direct and indirect influences of temperature on the analyzed parameters were as follows: 0.12 and 0.22 for RCP2.6, -0.01 and 0.13 for RCP4.5, -0.19 and 0.09 for RCP6.0, and -0.23 and 0.09 for RCP8.5. This means that the minimum and maximum values of indirect influence of climate change for each RCP scenario, obtained by subtracting the value of direct influence from the sum of direct and indirect influence of climate change, were: 0.57 and 0.67 for RCP2.6, 0.68 and 0.94 for RCP4.5, for 0.65 and 1.23 RCP6.0, 0.60 and 1.71 for RCP8.5. 
Table 12. Linolenic acid content in oilseed rape seeds calculated for the period of 1986-2005 and predicted for four RCP scenarios (2.6, 4.5, 6.0, 8.5) and four periods (2020-2039, 2040-2059, 2060-2079, 2080-2099) in simulations allowing for the direct and indirect influence of climate change.

\begin{tabular}{|c|c|c|c|c|c|c|c|c|c|c|c|c|c|c|c|c|c|c|c|c|c|}
\hline \multirow{4}{*}{ Location } & \multicolumn{21}{|c|}{ Period } \\
\hline & \multirow{3}{*}{ 1986-2005 } & \multicolumn{5}{|c|}{ 2020-2039 } & \multicolumn{5}{|c|}{ 2040-2059 } & \multicolumn{5}{|c|}{ 2060-2079 } & \multicolumn{5}{|c|}{ 208-2099 } \\
\hline & & \multicolumn{4}{|c|}{ RCP Scenario } & \multirow{2}{*}{$\mathrm{CV}$} & \multicolumn{4}{|c|}{ RCP Scenario } & \multirow{2}{*}{$\mathrm{CV}$} & \multicolumn{4}{|c|}{ RCP Scenario } & \multirow{2}{*}{$\mathrm{CV}$} & \multicolumn{4}{|c|}{ RCP Scenario } & \multirow{2}{*}{ CV } \\
\hline & & 2.6 & 4.5 & 6.0 & 8.5 & & 2.6 & 4.5 & 6.0 & 8.5 & & 2.6 & 4.5 & 6.0 & 8.5 & & 2.6 & 4.5 & 6.0 & 8.5 & \\
\hline Białystok & 10.00 & 10.04 & 10.14 & 10.07 & 9.97 & 0.69 & 10.00 & 9.91 & 9.98 & 9.85 & 0.69 & 9.97 & 9.81 & 9.86 & 9.65 & 1.36 & 9.95 & 9.83 & 9.75 & 9.62 & 1.42 \\
\hline Gdańsk & 10.28 & 10.31 & 10.39 & 10.32 & 10.29 & 0.43 & 10.29 & 10.22 & 10.30 & 10.22 & 0.40 & 10.31 & 10.20 & 10.21 & 10.13 & 0.75 & 10.31 & 10.23 & 10.14 & 10.08 & 1.00 \\
\hline Katowice & 9.89 & 10.06 & 10.09 & 10.04 & 10.02 & 0.27 & 10.01 & 9.89 & 9.97 & 9.87 & 0.64 & 9.97 & 9.77 & 9.81 & 9.63 & 1.41 & 9.99 & 9.79 & 9.71 & 9.59 & 1.72 \\
\hline Kielce & 9.90 & 10.04 & 10.09 & 10.05 & 9.99 & 0.41 & 9.99 & 9.89 & 9.99 & 9.85 & 0.71 & 9.99 & 9.80 & 9.83 & 9.62 & 1.53 & 9.99 & 9.82 & 9.70 & 9.53 & 2.01 \\
\hline Kraków & 9.76 & 9.92 & 9.94 & 9.92 & 9.88 & 0.24 & 9.88 & 9.77 & 9.85 & 9.77 & 0.58 & 9.85 & 9.67 & 9.71 & 9.57 & 1.22 & 9.86 & 9.69 & 9.62 & 9.53 & 1.43 \\
\hline Lublin & 9.92 & 9.99 & 10.04 & 10.02 & 9.94 & 0.45 & 9.95 & 9.85 & 9.93 & 9.76 & 0.85 & 9.93 & 9.72 & 9.78 & 9.55 & 1.60 & 9.91 & 9.74 & 9.65 & 9.49 & 1.81 \\
\hline Łódź & 9.83 & 10.03 & 10.06 & 10.03 & 9.96 & 0.44 & 9.96 & 9.84 & 9.94 & 9.76 & 0.92 & 9.90 & 9.70 & 9.77 & 9.54 & 1.51 & 9.91 & 9.69 & 9.65 & 9.49 & 1.79 \\
\hline Olsztyn & 10.02 & 10.17 & 10.26 & 10.15 & 10.14 & 0.52 & 10.12 & 9.99 & 10.12 & 10.05 & 0.62 & 10.13 & 9.90 & 10.00 & 9.86 & 1.19 & 10.09 & 9.95 & 9.89 & 9.80 & 1.24 \\
\hline Opole & 9.67 & 9.93 & 9.94 & 9.92 & 9.86 & 0.37 & 9.88 & 9.75 & 9.86 & 9.72 & 0.79 & 9.81 & 9.63 & 9.71 & 9.54 & 1.15 & 9.82 & 9.71 & 9.57 & 9.52 & 1.42 \\
\hline Poznań & 9.80 & 10.08 & 10.11 & 10.08 & 10.00 & 0.47 & 10.03 & 9.92 & 10.03 & 9.88 & 0.79 & 9.97 & 9.81 & 9.87 & 9.69 & 1.19 & 9.99 & 9.86 & 9.77 & 9.63 & 1.54 \\
\hline Rzeszów & 9.81 & 9.87 & 9.90 & 9.90 & 9.83 & 0.31 & 9.83 & 9.75 & 9.82 & 9.69 & 0.67 & 9.81 & 9.63 & 9.69 & 9.54 & 1.18 & 9.81 & 9.64 & 9.60 & 9.55 & 1.21 \\
\hline Szczecin & 9.97 & 10.27 & 10.34 & 10.27 & 10.24 & 0.43 & 10.22 & 10.15 & 10.24 & 10.11 & 0.62 & 10.17 & 10.06 & 10.12 & 9.99 & 0.77 & 10.20 & 10.11 & 10.01 & 9.97 & 1.03 \\
\hline Toruń & 9.77 & 9.99 & 10.03 & 9.99 & 9.93 & 0.41 & 9.94 & 9.83 & 9.92 & 9.78 & 0.75 & 9.88 & 9.72 & 9.79 & 9.63 & 1.10 & 9.87 & 9.75 & 9.69 & 9.61 & 1.15 \\
\hline Warszawa & 9.80 & 9.88 & 9.91 & 9.89 & 9.81 & 0.48 & 9.83 & 9.71 & 9.80 & 9.65 & 0.83 & 9.81 & 9.60 & 9.66 & 9.47 & 1.43 & 9.77 & 9.62 & 9.57 & 9.47 & 1.31 \\
\hline Wrocław & 9.79 & 10.07 & 10.09 & 10.06 & 10.02 & 0.29 & 10.02 & 9.92 & 9.98 & 9.91 & 0.52 & 9.97 & 9.83 & 9.89 & 9.76 & 0.92 & 10.00 & 9.89 & 9.78 & 9.71 & 1.27 \\
\hline $\begin{array}{l}\text { Ziel. } \\
\text { Góra }\end{array}$ & 9.77 & 10.12 & 10.15 & 10.09 & 10.04 & 0.46 & 10.04 & 9.93 & 10.05 & 9.88 & 0.82 & 9.98 & 9.82 & 9.88 & 9.70 & 1.19 & 10.00 & 9.87 & 9.76 & 9.65 & 1.52 \\
\hline Min & 9.67 & 9.87 & 9.90 & 9.89 & 9.81 & 0.24 & 9.83 & 9.71 & 9.80 & 9.65 & 0.40 & 9.81 & 9.60 & 9.66 & 9.47 & 0.75 & 9.77 & 9.62 & 9.57 & 9.47 & 1.00 \\
\hline $\max$ & 10.28 & 10.31 & 10.39 & 10.32 & 10.29 & 0.69 & 10.29 & 10.22 & 10.30 & 10.22 & 0.92 & 10.31 & 10.20 & 10.21 & 10.13 & 1.60 & 10.31 & 10.23 & 10.14 & 10.08 & 2.01 \\
\hline Mean & 9.87 & 10.05 & 10.09 & 10.05 & 10.00 & 0.42 & 10.00 & 9.90 & 9.99 & 9.86 & 0.70 & 9.97 & 9.79 & 9.85 & 9.68 & 1.22 & 9.97 & 9.82 & 9.74 & 9.64 & 1.43 \\
\hline $\mathrm{CV}$ & 1.47 & 1.25 & 1.42 & 1.20 & 1.34 & & 1.28 & 1.40 & 1.40 & 1.56 & & 1.39 & 1.61 & 1.53 & 1.83 & & 1.42 & 1.69 & 1.62 & 1.82 & \\
\hline
\end{tabular}


Table 13. Linolenic acid content in oilseed rape seeds calculated for the period of 1986-2005 and predicted for four RCP scenarios (2.6, 4.5, 6.0, 8.5) and four periods (2020-2039, 2040-2059, 2060-2079, 2080-2099) in simulations allowing for the direct influence of climate change.

\begin{tabular}{|c|c|c|c|c|c|c|c|c|c|c|c|c|c|c|c|c|c|}
\hline \multirow{4}{*}{ Location } & \multicolumn{17}{|c|}{ Period } \\
\hline & \multirow{3}{*}{ 1986-2005 } & \multicolumn{4}{|c|}{ 2020-2039 } & \multicolumn{3}{|c|}{ 2040-2059 } & & \multicolumn{4}{|c|}{ 2060-2079 } & \multicolumn{4}{|c|}{ 2080-2099 } \\
\hline & & \multicolumn{16}{|c|}{ RCP Scenario } \\
\hline & & 2.6 & 4.5 & 6.0 & 8.5 & 2.6 & 4.5 & 6.0 & 8.5 & 2.6 & 4.5 & 6.0 & 8.5 & 2.6 & 4.5 & 6.0 & 8.5 \\
\hline Białystok & 10.00 & 9.53 & 9.62 & 9.59 & 9.36 & 9.41 & 9.25 & 9.30 & 8.97 & 9.38 & 9.04 & 9.06 & 8.50 & 9.42 & 9.01 & 8.77 & 7.98 \\
\hline Gdańsk & 10.28 & 9.75 & 9.76 & 9.81 & 9.60 & 9.64 & 9.48 & 9.51 & 9.20 & 9.61 & 9.30 & 9.29 & 8.82 & 9.68 & 9.27 & 8.99 & 8.27 \\
\hline Katowice & 9.89 & 9.43 & 9.44 & 9.48 & 9.37 & 9.31 & 9.14 & 9.19 & 8.95 & 9.32 & 8.94 & 8.93 & 8.43 & 9.37 & 8.92 & 8.64 & 7.88 \\
\hline Kielce & 9.90 & 9.43 & 9.43 & 9.47 & 9.29 & 9.31 & 9.14 & 9.19 & 8.87 & 9.30 & 8.93 & 8.93 & 8.39 & 9.34 & 8.90 & 8.65 & 7.83 \\
\hline Kraków & 9.76 & 9.32 & 9.32 & 9.38 & 9.25 & 9.20 & 9.03 & 9.10 & 8.84 & 9.21 & 8.83 & 8.83 & 8.32 & 9.26 & 8.81 & 8.55 & 7.79 \\
\hline Lublin & 9.92 & 9.46 & 9.46 & 9.51 & 9.31 & 9.34 & 9.17 & 9.23 & 8.88 & 9.33 & 8.95 & 8.97 & 8.41 & 9.37 & 8.94 & 8.68 & 7.86 \\
\hline Łódź & 9.83 & 9.42 & 9.43 & 9.46 & 9.29 & 9.30 & 9.12 & 9.20 & 8.89 & 9.29 & 8.93 & 8.95 & 8.42 & 9.34 & 8.88 & 8.67 & 7.90 \\
\hline Olsztyn & 10.02 & 9.56 & 9.60 & 9.60 & 9.44 & 9.43 & 9.24 & 9.34 & 9.06 & 9.44 & 9.05 & 9.10 & 8.62 & 9.48 & 9.03 & 8.82 & 8.11 \\
\hline Opole & 9.67 & 9.27 & 9.29 & 9.30 & 9.18 & 9.15 & 8.98 & 9.05 & 8.77 & 9.15 & 8.78 & 8.79 & 8.26 & 9.21 & 8.78 & 8.51 & 7.76 \\
\hline Poznań & 9.80 & 9.40 & 9.44 & 9.45 & 9.30 & 9.29 & 9.13 & 9.21 & 8.89 & 9.29 & 8.94 & 8.95 & 8.42 & 9.35 & 8.94 & 8.66 & 7.93 \\
\hline Rzeszów & 9.81 & 9.38 & 9.37 & 9.45 & 9.28 & 9.26 & 9.08 & 9.16 & 8.86 & 9.27 & 8.87 & 8.89 & 8.34 & 9.30 & 8.86 & 8.61 & 7.82 \\
\hline Szczecin & 9.97 & 9.55 & 9.60 & 9.60 & 9.47 & 9.44 & 9.30 & 9.36 & 9.06 & 9.43 & 9.12 & 9.13 & 8.63 & 9.52 & 9.13 & 8.84 & 8.16 \\
\hline Toruń & 9.77 & 9.35 & 9.38 & 9.40 & 9.23 & 9.24 & 9.07 & 9.14 & 8.84 & 9.23 & 8.88 & 8.90 & 8.40 & 9.28 & 8.87 & 8.63 & 7.89 \\
\hline Warszawa & 9.79 & 9.38 & 9.40 & 9.44 & 9.25 & 9.27 & 9.09 & 9.17 & 8.86 & 9.33 & 8.89 & 8.91 & 8.38 & 9.30 & 8.88 & 8.65 & 7.87 \\
\hline Wrocław & 9.78 & 9.37 & 9.40 & 9.41 & 9.29 & 9.26 & 9.08 & 9.16 & 8.87 & 9.26 & 8.89 & 8.69 & 8.39 & 9.31 & 8.89 & 8.61 & 7.88 \\
\hline $\begin{array}{c}\text { Zielona } \\
\text { Góra }\end{array}$ & 9.77 & 9.36 & 9.40 & 9.38 & 9.27 & 9.25 & 9.09 & 9.17 & 8.85 & 9.25 & 8.91 & 8.91 & 8.39 & 9.31 & 8.91 & 8.62 & 7.89 \\
\hline Min & 9.67 & 9.27 & 9.29 & 9.30 & 9.18 & 9.15 & 8.98 & 9.05 & 8.77 & 9.15 & 8.78 & 8.69 & 8.26 & 9.21 & 8.78 & 8.51 & 7.76 \\
\hline Max & 10.28 & 9.75 & 9.76 & 9.81 & 9.60 & 9.64 & 9.48 & 9.51 & 9.20 & 9.61 & 9.30 & 9.29 & 8.82 & 9.68 & 9.27 & 8.99 & 8.27 \\
\hline Mean & 9.87 & 9.44 & 9.46 & 9.48 & 9.32 & 9.32 & 9.15 & 9.22 & 8.92 & 9.32 & 8.95 & 8.95 & 8.45 & 9.37 & 8.94 & 8.68 & 7.93 \\
\hline
\end{tabular}


Table 14. Changes of linolenic acid content predicted for four scenarios (RCP2.6, RCP4.5, RCP6.0, RCP8.5) and four periods (2020-2039, 2040-2059, 2060-2079, 2080-2099) influenced by climate change.

\begin{tabular}{|c|c|c|c|c|c|c|c|c|c|c|c|c|c|c|c|c|}
\hline \multirow{4}{*}{$\begin{array}{l}\text { Influence of } \\
\text { Climate } \\
\text { Change }\end{array}$} & \multicolumn{16}{|c|}{ Period } \\
\hline & \multicolumn{4}{|c|}{$2020-2039$} & \multicolumn{4}{|c|}{ 2040-2059 } & \multicolumn{4}{|c|}{ 2060-2079 } & \multicolumn{4}{|c|}{ 2080-2099 } \\
\hline & \multicolumn{16}{|c|}{ RCP Scenario } \\
\hline & 26 & 45 & 60 & 85 & 26 & 45 & 60 & 85 & 26 & 45 & 60 & 85 & 26 & 45 & 60 & 85 \\
\hline $\begin{array}{l}\text { Direct }+ \\
\text { indirect }\end{array}$ & 0.18 & 0.22 & 0.18 & 0.12 & 0.13 & 0.02 & 0.11 & -0.01 & 0.09 & -0.08 & -0.02 & -0.19 & 0.09 & -0.05 & -0.13 & -0.23 \\
\hline Direct & -0.44 & -0.41 & -0.39 & -0.55 & -0.55 & -0.72 & -0.66 & -0.96 & -0.56 & -0.92 & -0.92 & -1.43 & -0.51 & -0.93 & -1.19 & -1.95 \\
\hline Indirect & 0.61 & 0.63 & 0.57 & 0.67 & 0.68 & 0.75 & 0.77 & 0.94 & 0.65 & 0.84 & 0.90 & 1.23 & 0.60 & 0.88 & 1.06 & 1.71 \\
\hline
\end{tabular}


Under the scenarios of RCP2.6 for the periods of 2060-2079, the locations are grouped into two clusters (Figure 4). Four clusters were distinguished under the RCO6.0 scenario for the periods of 2060-2079 and 2080-2099, and under RCP8.5 scenario for the period of 2060-2079, while for the other combinations of scenario and period, the locations were grouped into three clusters.

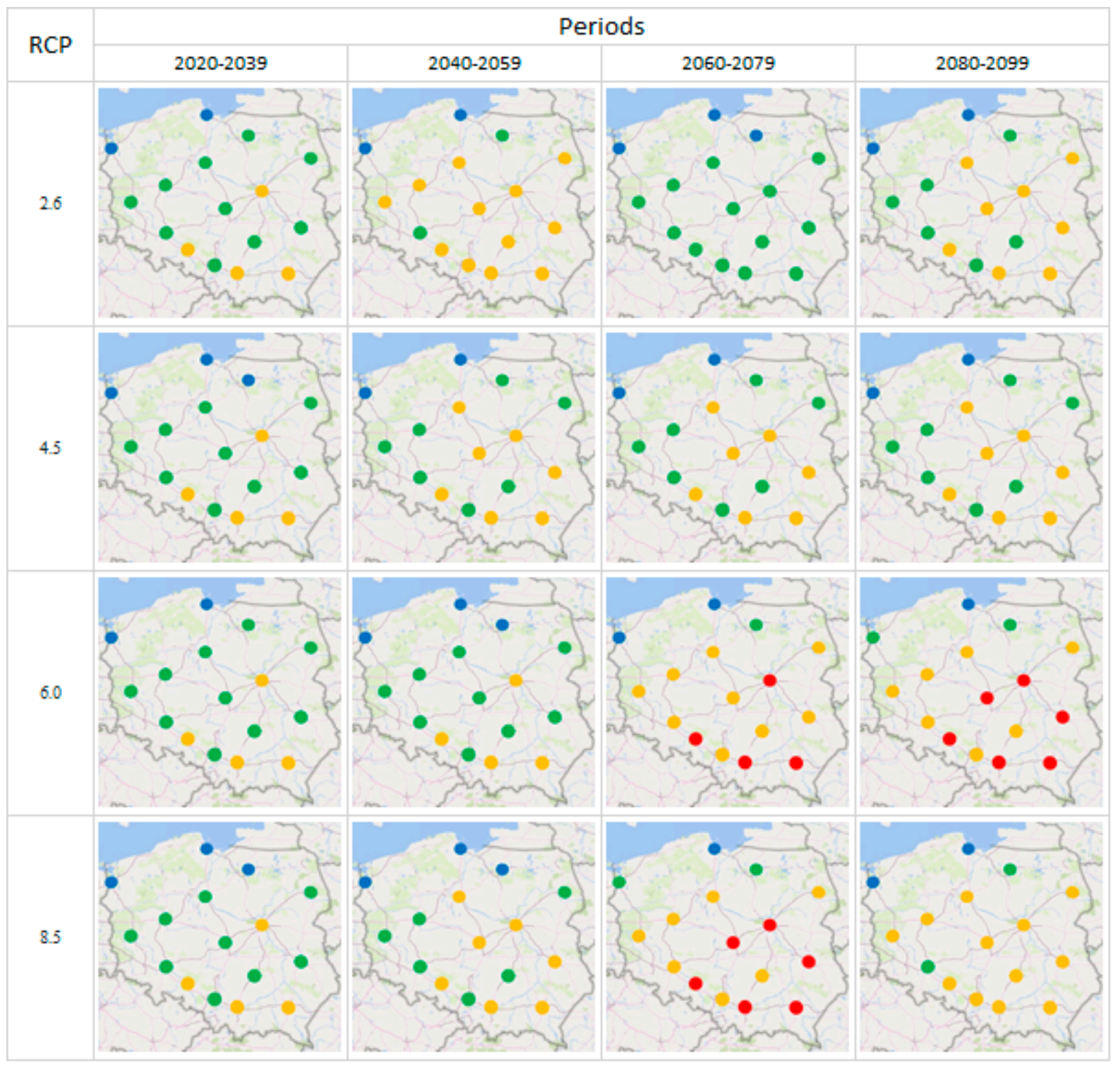

Figure 4. Results of clustering the locations according to the value of linolenic acid content for four RCP scenarios $(2.6,4.5,6.0,8.5)$ and four periods (2020-2039, 2040-2059, 2060-2079, 2080-2099). Locations in the same cluster are marked with the same color.

The comparison of the clustered results revealed that Gdańsk (16 times) and Szczecin (14 times) appeared most frequently in the cluster with the lowest acid content. Kraków (16 times), Opole (16 times), Rzeszów (16 times), and Warszawa (16 times) were most often classified into the cluster with the highest acid content.

\section{Discussion}

The agreement between the results of observations and the simulations based on mean results of two models $(\mathrm{m}+\exp$ and lo $+\exp )$ indicates that the equation developed for predicting the onset of 
the beginning of oilseed rape maturity (BBCH 81$)$ can be applied as a sub-model in simulations aimed at prediction of linolenic acid content in oilseed rape seeds under climate change scenarios.

The results of simulations performed with that sub-model indicate acceleration of oilseed rape development in the future (2020-2039, 2040-2059, 2060-2079, 2080-2099) compared to the development in the past (1986-2005). This is consistent with findings of Racca et al. [31] who using winter oilseed rape phenological model showed earlier onset of four phenological stages (BBCH 51, 55, 61, 65, 69) for oilseed rape in two regions of Lower Saxony for the periods of 2020-2050 and 2070-2100. Spatial variation of the rate of oilseed development showed in our study also corroborate results presented by Racca et al. [31], who recorded differences between the regions analyzed in the appearance of the four BBCH stages for the period of 2070-2100.

We described the relationship between linolenic acid content and temperature using a linear regression equation, which corroborates the approach adopted earlier in [18] to estimate the effect of temperature on fatty acids composition in conventional cultivars of oilseed rape in Switzerland. Discussing the results, the authors of that study stressed that linear regression being characterized only by two parameters (slope and intercept) minimizes errors due to parameter estimation. The equation presented in [18] explains approximately half of the variability in linolenic acid content, which did not differ from findings reported in our study. The results obtained could be improved by including more genotypes, years, and locations. However, this deficiency was compensated for, to some extent, by the great number of plots.

The results of the simulations performed under all tested scenarios (RCP2.6, RCP4.5, RCP6.0, RCP8.5) for all analyzed periods (2020-2039, 2040-2059, 2060-2079, 2080-2099) indicate a reduction of linolenic acid content as an effect of climate change. These findings corroborate the results of Namazkar et al. [32,33], who reported a reduction of linolenic acid content in seeds of oilseed rape grown in future climate scenarios with an elevated temperature. The changes of fatty acids composition are induced by variations in temperature during seed development [15]. Conventional oilseed rape oil contains approximately $6 \%$ saturated fatty acids (C16:0 + C18:0), 55-60\% oleic acid (C18:1), 20-26\% linoleic acid (C18:2), and 8-10\% linolenic acid (C18:3). Of the fatty acids of oilseed rape, oleic acid (C18:1) and linolenic acid (C18:3) are most sensitive to temperature changes [17]. Higher temperatures during seed maturation are known to be conductive for the formation of more oleic acid, and lower temperatures for formation of linolenic acid, which is the product of linoleic acid desaturation. The final amount of linolenic acid depends on the desaturation rate of $\mathrm{C} 18: 1$ to $\mathrm{C} 18: 2$, and then of $\mathrm{C} 18: 2$ to C18:3. The negative correlation of oleic acid with linolenic acid presented in [30] corroborates the close relationship between unsaturated fatty acids content and indirectly explains the role of desaturase in shaping the final fatty acids composition.

A similar process is observed during sunflower seeds development [34]. Since sunflower does not contain linolenic acid, low temperatures result in higher linoleic acid content. The increase in linoleic acid at low temperatures may be attributed to an enhanced synthesis or activity of the enzyme oleyl-CoA desaturase, which is responsible for converting oleic acid to linoleic acid [35].

The negative effects of elevated temperature on linolenic acid content in seeds of oilseed rape presented in our study corroborate the findings of Deng and Scarth [15], who analyzed fatty acid composition in three temperature regimes and stated that the highest linolenic acid content occurred under the lowest temperature treatment, whereas the lowest was under the highest temperature treatment. This is also consistent with results obtained by Tremolieres et al. [14], who showed an increase in linolenic acid content in mature seed oil as an effect of exposure of oilseed rape plants to low temperatures $\left(12-17^{\circ} \mathrm{C}\right)$. The effect of temperature on the fatty acid composition was also studied in seeds of soybean $[36,37]$ and flax [38,39]. These studies also showed a decrease of fatty acids desaturation when the crops were grown at higher temperatures. Moreover, in soybean seeds [37], a close relationship between unsaturated fatty acids content was confirmed by the significant negative correlation of oleic acid content with the content of linoleic and linolenic acids. 
Interesting results of a study focused on environmental effects on oil quality of oilseed crops are also presented by Roche et al. [40], who stated differentiating effects of climatic conditions not only on fatty acids compositions, but also on phytosterols content in safflower seeds. According to Belo et al. [41], the impact of environment on phytosterols depends on the plant species. Changes of these bioactive compounds' concentration due to variations of temperature were found in soybean and sunflower seeds [42,43], while no temperature effect on phytosterols has been reported in canola seeds [44].

The comparison of simulation results obtained with and without allowing for the influence of temperature on oilseed rape development presented in our study revealed that global warming will increase the significance of the direct influence on the modification of the linolenic acid content. An analysis of the results obtained indicates that the indirect influence of climate change expressed in changes of linolenic acid content generated by the acceleration of oilseed rape maturation reduces the direct influence of climate change expressed as changes of linolenic acid content caused by temperature. The importance of indirect influence in modifying the linolenic acid content was particularly evident in the results of simulations performed under the RCP8.5 scenario. In this case, linolenic acid content obtained in simulations without allowing for the influence of climate change on oilseed rape maturation was reduced from 9.34 for the period of 2020-2039 to 8.03 for 2080-2099; whereas linolenic acid content obtained in simulations performed allowing for the effect of climate change on oilseed rape for the same periods were 9.89 and 9.59 , respectively.

The small values of coefficient of variance $(\mathrm{CV})$ obtained in the comparisons of linolenic acid content under the four RCP scenarios for all studied locations proves the high credibility of results obtained in simulations for all the analyzed periods. However, changes in the value of $\mathrm{CV}$ over the course of time indicates differences in the credibility of predictions. The smallest value of $\mathrm{CV}$ for the period of 2020-2039 (0.38), and the highest for the period of 2080-2099 (1.31), indicate that the forecasts for these periods are the most and the least reliable, respectively; whereas predictions for the periods of 2040-2059 (0.64) and 2060-2079 (1.11) seem to be of medium credibility.

Results of clustering indicate that the predicted climate changes will cause an increase in the cultivation area of oilseed rape characterized by a reduced content of linolenic acid. This is particularly clearly indicated by the increase in the number of locations included in the cluster with a lower linolenic acid content recorded when comparing the periods of 2020-2039 and 2080-2099 under the RCP6.0 and RCP 8.5 scenarios. However, the simulations performed indicated also locations included most often in the same cluster. Regions with favorable conditions for the production of rape with the highest (Gdańsk, Szczecin) and the lowest (Kraków, Opole, Rzeszów, Warsaw) content of linolenic acid were distinguished this way. The former would allow for the harvesting of oilseed rape seeds with acid content most similar to that obtained so far. Meteorological conditions in the latter regions would be conducive to the production of oilseed rape aimed at obtaining oil with greater durability, which is important both as a raw material intended for human consumption and for the production of biofuels. Therefore, the results of the simulations presented indicate that the future climate change will not negatively affect the bio-fuel quality. On the other hand, linolenic acid not being synthesized by humans is preferred in a human diet, since it is assume to reduce risk of cardiovascular diseases. Therefore, decrease of its content in the oil of oilseed rape may degrade the quality of oil for consumption and pose a serious challenge for the oil producers in the future. It must be stressed that temperature is not the only parameter which affects the linolenic acid content. Elevation of $\mathrm{CO}_{2}$ and $\mathrm{O}_{3}$ and may also trigger the changes in the oil quality. Moreover, the model used in our study does not include characteristics related to genotypic variability of the future cultivars. However, comparison of results presented in [30] showed that variability of linolenic acid content due to differences in temperature between the years of the experiment was approximately ten times bigger than that caused by differences in genotypes of the cultivars used. This is consistent with findings presented in [18] by Baux et al., who for most oilseed rape cultivars tested in the study also observed a greater effect of climate change than genotypic variability on linolenic acid content. Therefore, according to these authors, the potential of 
the year and location for changing linolenic acid content in oilseed rape seeds can be estimated using average regression parameters.

However additional work aimed at determining not only the effect of cultivar variability, but also other factors like radiation and drought on fatty acids composition, is necessary.

Author Contributions: Conceptualization, M.W.; methodology, M.W. and A.W.; data analysis, M.W. and A.W.; writing-original draft preparation M.W. and A.W.; writing-review and editing, M.W. and A.W.; All authors have read and agreed to the published version of the manuscript.

Funding: This research received no external funding.

Conflicts of Interest: The authors declare no conflict of interest.

\section{References}

1. Singh, S.K.; Kakani, V.G.; Brand, D.; Baldwin, B.; Reddy, K.R. Assessment of cold and heat tolerance of winter-grown canola (Brassica napus L.) cultivars by pollen-based parameters. J. Agron. Crop. Sci. 2008, 194, 225-236. [CrossRef]

2. Tassone, E.E.; Lipka, A.E.; Tomasi, P.; Lohrey, G.T.; Qian, W.; Dyer, J.M.; Gore, M.A.; Jenks, M.A. Chemical variation for leaf cuticular waxes and their levels revealed in a diverse panel of Brassica napus L. Ind. Crop. Prod. 2016, 79, 77-83. [CrossRef]

3. Liu, S.; Li, L.; Gao, W.; Zhang, Y.; Liu, Y.; Wang, S.; Lu, J. Diagnosis of nitrogen status in winter oilseed rape (Brassica napus L.) using in-situ hyperspectral data and unmanned aerial vehicle (UAV) multispectral images. Comput. Electron. Agric. 2018, 151, 185-195. [CrossRef]

4. Carré, P.; Pouzet, A. Rapeseed market; worldwide and in Europe. OCL 2014, 21, D102. [CrossRef]

5. USDA. Oilseeds: World Markets and Trades Circular series FOP 03-11 United States Departments of Agriculture. Foreign Agricultural Service; 2011. Available online: http:/www.fas.usda.gov/oilseeds/circular/ 2011/March/oilseeds.pdf (accessed on 10 May 2020).

6. Naeem, M.S.; Jin, Z.L.; Wan, G.L.; Liu, D.; Liu, H.B.; Yoneyama, K.; Zhou, W.J. 5-Aminolevulinic acid improves photosynthetic gas exchange capacity and ion uptake under salinity stress in oilseed rape (Brassica napus L.). Plant Soil 2010, 332, 405-415. [CrossRef]

7. Lee, B.R.; Zaman, R.; Avice, J.C.; Ourry, A.; Kim, T. Sulfur yuse efficiency is a significant determinant of drought stress tolerance in relation to photosynthetic activit in Brassica napus cultivars. Front. Plant Sci. 2016, 7, 459. [CrossRef]

8. Milošević, D.; Ignjatov, M.; Nikolic, Z.; Stankovic, I.; Bulajić, A.; Jeromela, A.; Krstić, B. The presence of turnip yellows virus in oilseed rape (Brassica napus L.) in Serbia. Pestic. Phytomed. 2016, 31, 37-44. [CrossRef]

9. SYOA. Statistical Yearbook of Agriculture; Central Statistical Office: Warszawa, Poland, 2017; p. 485.

10. Orlovius, K. Oilseed rape. In Fertilizing for High Yield and Quality; Kirbky, E.A., Ed.; IPI Bulletin: Basel, Switzerland, 2003; Volume 16, p. 125.

11. Wittkop, B.; Snowdon, R.J.; Friedt, W. Status and perspectives of breeding for enhanced yield and quality of oilseed crops for Europe. Euphytica 2009, 170, 131-140. [CrossRef]

12. Gauthier, M.; Pellet, D.; Monney, C.; Herrera, J.; Rougier, M.; Baux, A. Fatty acids composition of oilseed rape genotypes as affected by solar radiation and temperature. Field Crop. Res. 2017, 212, 165-174. [CrossRef]

13. Canvin, D.T. The effect of temperature on the oil content and fatty acid composition of the oils from several oil seed crop Can. J. Bot. 1965, 43, 63-69. [CrossRef]

14. Tremolieres, H.A.; Tremolieres, A.; Mazliak, P. The Effects of light and temperature on the fatty acid desaturation during the maturation of rapeseed. Phytochemistry 1977, 17, 685-687. [CrossRef]

15. Deng, X.; Scarth, R. Temperature effects on fatty acid composition during development of low-linolenic oilseed rape (Brassica napus L.). J. Am. Oil Chem. Soc. 1998, 75, 759-766. [CrossRef]

16. Triboi-Blondel, A.M.; Renard, M. Effects of temperature and water stress on fatty acid composition of rapeseed oil. In Proceedings of the 10th International Rapeseed Congress, Canberra, Australia, 26-30 March 1999.

17. Baux, A.; Hebeisen, T.; Pellet, D. Effects of minimal temperatures on low-linolenic rapeseed oil fatty-acid composition. Eur. J. Agron. 2008, 29, 102-107. [CrossRef]

18. Baux, A.; Colbach, N.; Allirand, J.M.; Jullien, A.; Ney, B.; Pellet, D. Insights into temperature effects on the fatty acid composition of oilseed rape varieties. Eur. J. Agron. 2013, 49, 12-19. [CrossRef] 
19. Moss, R.; Edmonds, J.; Hibbard, K.; Manning, M.; Rose, S.; Vuuren, D.; Carter, T.; Emori, S.; Kainuma, M.; Kram, T.; et al. The next generation of scenarios for climate change research and assessment. Nature 2010, 463, 747-756. [CrossRef]

20. Van Vuuren, D.P.; Edmonds, J.; Kainuma, M.; Riahi, K.; Thomson, A.; Hibbard, K.; George, C.; Hurtt, G.C.; Kram, T.; Krey, V.; et al. The representative concentration pathways: An overview. Clim. Chang. 2011, 109, 5-31. [CrossRef]

21. Van Vuuren, D.P.; Den Elzen, M.G.J.; Lucas, P.L.; Eickhout, B.; Strengers, B.J.; van Ruijven, B.; Wonink, S.; van Houdt, R. Stabilizing greenhouse gas concentrations at low levels: An assessment of reduction strategies and costs. Clim. Chang. 2007, 81, 119-159. [CrossRef]

22. Clarke, L.; Edmonds, J.; Jacoby, H.; Pitcher, H.; Reilly, J.; Richels, R. Scenarios of Greenhouse Gas Emissions and Atmospheric Concentrations; Sub-Report 2.1A of Synthesis and Assessment Product 2.1 by the U.S. Climate Change Science Program and the Subcommittee on Global Change Research; Department of Energy; Office of Biological and Environmental Research: Washington, DC, USA, 2007; p. 154.

23. Smith, S.J.; Wigley, T.M.L. Multi-gas forcing stabilization with the MiniCAM. Energy J. 2006, $27,373-391$. [CrossRef]

24. Wise, M.; Calvin, K.; Thomson, A.; Clarke, L.; Sands, R.; Smith, S.J.; Janetos, A.; Edmonds, J. Implications of limiting $\mathrm{CO}_{2}$ concentrations for land use and energy. Science 2009, 324, 1183-1186. [CrossRef]

25. Fujino, J.; Nair, R.; Kainuma, M.; Masui, T.; Matsuoka, Y. Multigas mitigation analysis on stabilization scenarios using aim global model. Energy J. Special Issue 2006, 3, 343-354.

26. Hijioka, Y.; Matsuoka, Y.; Nishimoto, H.; Masui, M.; Kainuma, M. Global GHG emissions scenarios under GHG concentration stabilization targets. J. Global Environ. Eng. 2008, 13, 97-108.

27. Riahi, K.; Krey, V.; Rao, S.; Chirkov, V.; Fischer, G.; Kolp, P.; Kindermann, G.; Nakicenovic, N.; Rafai, P. RCP 8.5-A scenario of comparatively high greenhouse gas emissions. Clim. Chang. 2011, 109, 33-57. [CrossRef]

28. Meier, U.; Bleiholder, H. BBCH Skala. Phänologische Entwicklungsstadien Wichtiger Landwirtschaftlicher Kulturen, Einschließlich Blattgemüse und Unkräuter; Agrimedia GmbH: Bergen/Dumme, Germany, 2006; p. 70.

29. Taylor, K.E. Summarizing multiple aspects of model performance in a single diagram. J. Geophys. Res. 2001, 106, 7183-7192. [CrossRef]

30. Wójtowicz, M. Effect of environmental and agronomical factors on quantity and quality of winter oilseed rape yield (Brassica napus L.). In Monographs and Disertations; IHAR-PIB: Radzików, Poland, 2013; Volume 45, p. 111. (In Polish)

31. Racca, P.; Kakau, J.; Kleinhenz, B.; Kuhn, C. Impact of climate change on the phenological development of winter wheat; sugar beet and winter oilseed rape in Lower Saxony; Germany. J. Plant Dis. Protect. 2015, 122, 16-27. [CrossRef]

32. Namazkar, S.; Egsgaarda, H.; Frenckb, G.; Terkelsenc, T.; Jørgensena, R.B. Significant reductions in oil quality and lipid content of oilseed rape (Brassica napus L.) under climate change. Procedia Environ. Sci. 2015, 29, 121-122. [CrossRef]

33. Namazkar, S.; Stockmarr, A.; Frenck, G.; Egsgaard, H.; Terkelsen, T.; Mikkelsen, T.; Ingvordsen, C.H.; Jørgensen, R.B. Concurrent elevation of $\mathrm{CO}_{2} ; \mathrm{O}_{3}$ and temperature severely affects oil quality and quantity in rapeseed. J. Exp. Bot. 2016, 14, 4117-4125. [CrossRef]

34. Izquierdo, N.; Aguirrezabal, L.; Andrade, F.; Pereyra, V. Night temperature affects fatty acid composition in sunflower oil depending on the hybrid and the phonological stage. Field Crop. Res. 2002, 77, 115-126. [CrossRef]

35. Tremolieres, A.; Dubaco, J.; Drapier, D. Unsaturated fatty acids in maturing seeds of sunflower and rape: Regulation by temperature and light intensity. Phytochemistry 1982, 24, 41-45. [CrossRef]

36. Thomas, J.M.G.; Boote, K.J.; Allen, L.H.; Gallo-Meagher, M.; Davis, J.M. Elevated temperature and carbon dioxide effects on soybean seed composition and transcript abundance. Crop. Sci. 2003, 43, 1548-1557. [CrossRef]

37. Kumar, V.; Rani, A.; Solanki, S.; Hussain, S.M. Influence of growing environment on the biochemical composition and physical characteristics of soybean seed. J. Food Compos. Anal. 2006, 19, 188-195. [CrossRef]

38. Nagao, A.; Yamazaki, M. Effect of temperature during maturation on fatty acid composition of sunflower seed. Agric. Biol. Chem. 1984, 48, 553-555.

39. Yermanos, D.M.; Gooden, J.R. Effect of temperature during plant development on the fatty acid composition of linseed oil. Agron. J. 1965, 57, 453-454. [CrossRef] 
40. Roche, J.; Mouloungui, Z.; Cerny, M.; Merah, O. Effect of sowing dates on fatty acids and phytosterols patterns of Carthamus tinctorius L. Appl. Sci. 2019, 9, 2839. [CrossRef]

41. Belo, R.G.; Velasco, L.; Nolasco, S.M.; Izquierdo, N.G. Oil phytosterol concentration in sunflower presents a dilution response with oil weight per grain. J. Am. Oil Chem. Soc. 2019, 96, 1115-1123. [CrossRef]

42. Roche, J.; Bouniols, A.; Mouloungui, Z.; Barranco, T.; Cerny, M. Management of environmental crop conditions to roduce useful sunflower oil components. Eur. J. Lipid Sci. Tech. 2006, 108, 287-297. [CrossRef]

43. Vlahakis, C.; Hazebroek, J. Phytosterol accumulation in canola, sunflower, and soybean oils: Effects of genetics, planting location, and temperature. J. Am. Oil Chem. Soc. 2000, 77, 49-53. [CrossRef]

44. Hamama, A.A.; Bhardwaj, H.L.; Starner, D.E. Genotype and growing location effects on phytosterols in canola oil. J. Am. Oil Chem. Soc. 2003, 80, 1121-1126. [CrossRef]

Publisher's Note: MDPI stays neutral with regard to jurisdictional claims in published maps and institutional affiliations.

(C) 2020 by the authors. Licensee MDPI, Basel, Switzerland. This article is an open access article distributed under the terms and conditions of the Creative Commons Attribution (CC BY) license (http://creativecommons.org/licenses/by/4.0/). 